
ISSN : 2615-1995, E-ISSN : 2615-0654

J. Madani., Vol. 2, No. 2, September 2019 (304 - 313)

(C)2018 Lembaga Kajian Demokrasi

MADANI

dan Pemberdayaan Masyarakat (LKD-PM)

\title{
Analisis Pengaruh Manajemen Sumber Daya Manusia Terhadap Nilai Hasil Belajar Peserta Didik Pada SMPN 11 Kota Tangerang Selatan
}

\author{
Yusuf Supardi \\ Fakultas Ekonomi, Universitas Pamulang \\ dosen01833@unpam.ac.id
}

\begin{abstract}
Abstrak
Penelitian ini dilaksanakan bertujuan untuk mengetahui ada atau tidaknya pengaruh manajemen sumber daya manusia terhadap nilai hasil belajar peserta didik pada SMPN 11 Kota Tangerang Selatan. Penelitian ini menggunakan metode survei dan metode kuantitatif, pengambilan sampel menggunakan metode sampel jenuh dalam arti seluruh populasi dijadikan sampel. Jumlah sampel pada penelitian ini sebanyak 65 guru. Sampel yang diamati dan diteliti adalah para guru yang melaksanakan tugas selama Oktober sampai dengan Desember 2018 pada SMPN 11 Kota Tangerang Selatan. Koefisien korelasi antara manajemen sumber daya manusia terhadap nilai hasil belajar peserta didik pada SMPN 11 Kota Tangerang Selatan sebesar 0,723, menunjukan manajemen sumber daya manusia dengan nilai hasil belajar peserta didik mempunyai hubungan kuat. Koefisien determinasi manajemen sumber daya manusia berpengaruh sebesar 72,3\%. Hal menunjukan bahwa besarnya kontribusi atau pengaruh manajemen sumber daya manusia terhadap nilai hasil belajar peserta didik pada SMPN 11 Kota Tangerang Selatan sebesar 72,3\%, sedangkan sisanya sebesar 27,7\% dipengaruhi faktor lain. Uji signifikansi diperoleh $t_{\text {hitung }} 8.303>t_{\text {table }} 1,997$, artinya terdapat hubungan positif dan signifikan antara manajemen sumber daya manusia terhadap nilai hasil belajar peserta didik pada SMPN 11 Kota Tangerang Selatan.Hasil uji regresi linear sederhana pada manajemen sumber daya manusia adalah $Y=4.010+0.895 X$, menyatakan bahwa setiap penambahan satu satuan manajemen sumber daya manusia akan meningkatkan nilai hasil belajar peserta didik pada SMPN 11 Kota Tangerang Selatan sebesar 0,895.
\end{abstract}

Kata Kunci : Manajemen Sumber Daya Manusia, Nilai Hasil Belajar Peserta Didik

\begin{abstract}
The research was conducted aiming to determine whether or not the influence of human resource management on the value of the study of students at SMPN 11 South Tangerang City. This study used survey method and quantitative methods, sampling methods saturated samples within the meaning of the entire population sampled. Number of samples in this study were 65 teachers. Samples were observed and researched is the teachers who carry out tasks for October to December 2018 at SMPN 11 South Tangerang City. The correlation coefficient between the management of human resources to the value of the study of students at SMPN 11 South Tangerang City of 0.723, indicating human resource management with the value of the study of students have a strong relationship. The coefficient of determination influential human resource management of $72.3 \%$. It shows that the size of the contribution or influence of human resource management on the value of the study of students at SMPN 11 South Tangerang city of 72.3\%, while the remaining 27.7\% influenced by other factors.Significance test 8303 obtained $t_{\text {count }}>t_{\text {table }} 1.997$, meaning that there is a positive and significant relationship between human resource management on the value of the study of students at SMPN 11 South Tangerang City. Results of simple linear regression test on human resource management is $Y=4010+0895 X$, stating that each additional unit of human resource management will enhance the value of the study of students at SMPN 11 South Tangerang
\end{abstract}


City at 0.895 .

Keywords : Management of Human Resources, the Value Of Learning Outcomes Of Students

\section{PENDAHULUAN}

\section{Latar Belakang}

Berdasarkan Pembukaan Undang-undang Dasar Negara Republik Indonesia tahun 1945, alinea ke empat dikatakan bahwa .... Membentuk suatu Pemerintah Negara Indonesia yang melindungi sgenap bangsa Indonesia dan seluruh tumpah darah Indonesia dan untuk mewujudkan kesejahteraan umum, mencerdaskan kehidupan bangsa.

Kewajiban pemerintah dalam pendidikan tersurat pula dalam Undang-undang Dasar Negara Republik Indonesia Tahun 1945, yang mengamanatkan Pemerintah untuk mengusahakan dan menyelenggarakan satu sistem pendidikan nasioanl yang meningkatkan keimanan dan ketaqwaaan.... serta akhlak mulia.

Sementara dalam undang-undang sistem pendidikan pasal 5 ayat (1) dikatakan bahwa setiap warga negera mempunyai hak yang sama untuk memperoleh pendidikan yang bermutu.

Selanjutnya dalam pasal 6, setiap warga $\mathrm{Ne}$ gara yang berusia tujuh tahun sampai dengan usia 15 tahun wajib mengikuti pendidikan dasar, dan pasal 12 ayat (1) sub c, setiap peserta didik pada setiap satuan pendidikan berhak mendapatkan beasiswa bagi yang berprestasi yang orang tuanya tidak mampu membiayai pendidikan.

Sementara Tap MPR RI omor IV/MPR/1999, tentang Garis Garis Besar Haluan Negara, pada Bab II kondisi Umum, dikatakan bahwa di bidang pendidikan masalah yang dihadapi adalah berlangsungnya pendidikan yang kurang bermakna bagi perkembangan pribadi dan watak anak, yang berakibat hilangnya kepribadian dan kesadaran akan makna hakiki kehidupan.

Untuk memecahkan peemasalahan tersebut di atas, maka Pamerintah bersama DPR membuat Undang-undang Republik Indonesia tentang sistem Pendidikan nasional, yang mengatakan bahwa sistem pendidikan nasional harus mampu menjamin pmerataan kesempatan pendidikan, peningkatan mutu, relevansi dan effisiensi mana- jemen pendidikan untuk menghadapi tantangan sesuai dengan tuntutan perubahan kehidupan. pembaharuan pendidikan serta terencana terarah dan berkesinambungan.

Pendidikan formal dilaksanakan pemerintah dan swasta, dalam mewujudkan sumber daya manusia yang menguasai iptek dan iptak, agar manusia Indonesia dimasa yang akan datang tidak tertinggal dari negara lain. Pada dasarnya pendidikan tidak hanya dilaksanakan lembaga formal namun juga dilaksanakan lembaga non formal.

Pendidikan pertama dan utama dilaksanakan oleh keluarga di rumahnya, semenjak lahir sampai usia enam tahun yang dikenal dengan nama pendidikan anak usia dini, pendidikan ini yang akan meningkatkan sumber daya manusia yang potensial, dalam arti anak tersebut benar-benar siap untuk melanjutkan pendidikan pada lembaga formal yang lebih tinggi.

Pendidikan kedua dilaksanakan dilingkungan sekolah dalam usia tujuh sampai dengan 15 tahun, yang dikenal dengan pendidikan dasar sembilan tahun (wajardikdas), dalam hal ini dilaksanakan dilingkungan sekolah dasar dan sekolah lanjutan tingkat pertama (SLTP).

Untuk mencetak sumber daya manusia yang mengusai iptek dan iptak, tentu harus dimulai dengan sumberdaya manusia yang mengusai iptek dan iptak itu sendiri, yang dapat melaksanakan tugas fungsinya dalam mengelola, membimbing dan mengarahkan peserta didik guna mencapai peserta didik yang berprestasi, yang dipantau dengan nilai hasil peserta didik itu sendiri.

Manajemen sumber daya manusia dalam hal ini guru, akan bisa mencetak peserta didik yang berkualitas apabila menguasai dasar sebagai pendidik dalam arti menguasai dan mampu melaksanakan tugas sesuai dengan keilmuannya atau sesuai dengan jurusan pendidikannya.

Namun demikian, saat ini kita mengetahui bahwa jumlah guru yang mengajar sesuai dengan jurusan pendidikannya belum terpenuhi, sehingga masih ada sekolah yang mempunyai 
jumlah guru belum mencapai ideal.

Dengan kata lain, masih terdapat guru merangkap memberikan materi pelajaran lain yang tidak sesuai dengan jurusan pendidikannya.

Sementara itu, siswa usia SLTP terus meningkat, sedangkan fasilitas ruangan kelas sangat terbatas, sehingga melampaui batas ideal. Idealnya satu kelas menampung 30 orang peserta didik, namun salam kenyataannya per kelas menampung 40 bahkan 45 orang peserta didik.

1. Perumusan masalah.

a. Bagaimana manajemen sumber daya manusia dalam melaksanakan tugas dan fungsi untuk meningkatkan kualitas peserta didik di SMPN 11 Kota Tangerang Selatan.

b. Bagaimana cara belajar peserta didik dalam rangka meningkatkan nilai hasil belajar di SMPN 11 Kota Tangerang Selatan.

c. Seberapa besar pengaruh manajemen sumber daya manusia terhadap nilai hasil belajar peserta didik di SMPN 11 Kota Tangerang Selatan.

2. Tujuan Penelitian

a. Untuk mengetahui hubungan manajemen sumber daya manusia dalam hal ini guru pada SMPN 11 Kota Tangerang Selatan.

b. Untuk mengetahui kualitas nilai hasil peserta didik pada SMPN 11 Kota Tangerang Selatan.

c. Untuk mengetahui seberapa besar pengaruh manajemen sumber daya manusia terhadap nilai hasil peserta didik pada SMPN 11 Kota Tangerang Selatan.

\section{Tinjauan Pustaka}

1. Landasan Teori

Menurut Bambang Tri Cahyono, dalam bukunya "Manajemen Sumber Daya Manusia”, 1996:2, Manajemen Sumber Daya Manusia merupakan suatu gerakan pengakuan terhadap pentingnya unsur manusia sebagai sumber daya yang cukup potensial yang perlu dikembangkan sehingga mampu memberikan kontribusi yang maksimal bagi organisasi maupun pengembangan dirinya.

Hal yang sama dikatakan Agus Sunyoto, "Manajemen Sumber Daya Manusia", 1999; 22, manajemen sumber daya manusia dapat didefinisikan sebagai rangkaian tindakan dalam hal penarikan, seleksi, pengembangan, pemeliharaan, dan penggunaan sumber daya manusia bukan sumber daya lainnya untuk mencapai tujuan baik tujuan individual maupun organisasi.

Sementara itu, Handoko, 1992, mengatakan bahwa manajemen sumber daya manusia adalah rangkaian tindakan dalam hal penarikan tenaga kerja, seleksi tenaga kerja, pengembangan tenaga kerja, pemeliharaan, dan penggunaan sumber daya manusia untuk mencapai tujuan individu maupun tujuan organisasi.

Dari definisi tersebut di atas dapat disimpulkan bahwa pada dasarnya manajemen sumber daya manusia menunjukkan bahwa manusia bukan hanya bagian unsur produksi, tetapi juga bagian yang mempunyai tujuan individu sebagai manusia. Dahulu manusia merupakan aset atau kekayaan utama organisasi, oleh karena itu harus dipelihara dengan baik.

Dapat pula dikatakan bahwa manajemen sumber daya manusia adalah suatu pendekatan manusia yang berdasarkan pada tiga prinsip dasar yaitu sumber daya manusia merupakan harta yang paling penting dalam organisasi, keberhasilan sangat dimungkinkan apabila peraturan dan kebijakanaan serta prosedur saling berhubungan, kultur organisasi berasal dari organisasi itu sendiri.

Manajemen Sumber daya manusia yang dimaksudkan disini adalah Guru, dimana menurut Keputusan Menteri Negara Pendayagunaan Aparatus Negara Nomor 81 Tahun 1993, Bab I Ketentuan Umum, Pasal 1 ayat (1) dikatakan bahwa Guru adalah pegawai negeri sipil yang diberi tugas, tanggung jawab, wewenang dan hak secara penuh oleh pejabat yang berwenang untuk melaksanakan pendidikan dengan tugas utama mengajar 
peserta didik pada jenjang pendidikan dasar dan menengah termasuk taman kanak-kanak atau membimbing peserta didik pada pendidikan dasar dan menengah.

Sedangkan Undang-undang sistem pendidikan Nasioanl Bab I Ketentuan Umum Pasal 1 ayat (6) dikatakan bahwa Pendidik adalah tenaga kependidikan yang berkualitas sebagai guru, dosen, pamong belajar, widyaswara, tutor, instruktur, fasilitator dan sebutan lain yang sesuai dengan kekhususannya serta berpartisipasi dalam menyelenggarakan pendidikan.

Setelah kita mengetahui sumber daya manusia dalam hal ini dikenal dengan nama guru, kita beralih pada kualitas pendidikan. Kualitas pendidikan yang diupayakan terus ditingkatkan dalam upaya sadar mengubah sumber daya manusia untuk terus meningkatkan pengetahuannya yang didasarkan Pancasilan dan Undang-undang dasar 1945.

Hal ini dimaksudkan agar mampu menjamin pemerataan kesempatan pendidikan, peningkatan mutu pendidikan serta relevansi effisiensi manajemen pendidikan dalam rangka menghadapi tantangan sesuai dengan tuntutan perubahan kehidupan lokal, nasional, dan global. Oleh karena itu, perlu ada pembaharuan pendidikan secara terencana, terarah dan berkesinambungan.

Kualitas pendidikan yang diprioritaskan padapendidikan dasar dan menengah, dimana menurut Ing Wardiman Djojonegoro, dalam bukunya Lima Puluh Tahun Perkembangan Pendidikan Indonesia, 1995; 486, dikatakan sebagai berikut : “... peningkatan mutu pendidikan harus merupakan upaya memiliki dampak jangka panjang. Peningkatan mutu pendidikan yang bekelanjutan (sustainable quality improvement) yang akan diciptakan jika mutu pendidikan tersebut diperoleh melalui upaya lembaga pendidikan yang bersangkutan dalam penyelenggaraan program pendidikan.

Prioritas peningkatan mutu pendidikan pada jenjang pendidikan dasar dan menengah paling tidak akan menjawab lima per- masalahan pokok yang saat ini ada dan dipandang mendasar.

Pertama, rendahnya rata-rata pencapaian nilai ebtanas murni (NEM) dalam lima tahun terakhir. Kedua, bervariasinya angka NEM antara propinsi yang satu dengan propinsi lain sebagai indikator belum meratanya mutu pendidikan. Ketiga, rendahnya mutu guru berdasarkan indikator pendidikan dan hasil berbagai penelitian. Keempat, timpangnya persebaran guru berdasarkan studi yang diperlukan, ilmu-ilmu sosial dibandingkan dengan matematika atau IPA dan jumlah daerah yang satu dengan daerah lain. Kelima, rendahnya efiensi internal yang antara lain ditunjukkan oleh indikator lamanya waktu belajar siswa yang terbuang dan tahun biaya yang terbuang sebagai akibat masih tingginya angka mengulang kelas dan putus sekolah.

Sementara itu, pengukuran kualitas pendidikan juga dilihat dari hasil belajar yang menyangkut aspek kognitif, afektif dan psikomotor, sebagaimana disampaikan, Susanto (2013: 5), Pengertian hasil belajar adalah perubahan yang terjadi pada diri siswa, baik yang menyangkut aspek kognitif, afektif, dan psikomotor.

Sedangkan dalam Peraturan Menteri Pendidikan dan Kebudayaan Republik Indonesia Nomor 53 Tahun 2015 tentang Penilaian Hasil Belajar oleh Pendidik dan Satuan Pendidikan Dasar dan Pendidikan Menengah. Dijelaskan sebagai berikut :

Pertama, adalah sikap (afektif), penilaian lebih ditujukan untuk membina perilaku sesuai budi pekerti dalam rangka pembentukan karakter peserta didik sesuai dengan proses pembelajaran (Kemendikbud, 2015:9).

Kedua, kompetensi pengetahuan atau yang disebut ranah kognitif dilakukan dengan cara mengukur penguasaan peserta didik yang mencakup pengetahuan faktual, konseptual, dan prosedural dalam berbagai tingkatan proses berpikir (Kemendikbud, 2015:11).

Ketiga, Penilaian pengetahuan dan ke- 
terampilan harus mengacu kepada pemetaan kompetensi dasar yang berasal dari KI-3 dan KI-4 pada periode tertentu (Kemendikbud, 2015:37). Dari beberapa teknik penilaian yang dapat dilakukan dalam ranah psikomotorik ini, menggunakan teknik penilaian kinerja. Pelaksanaan kinerja perlu menyiapkan rubrik yang dituangkan dalam format observasi

2. Hipotesis

Berdasarkan hasil penelitian yang telah dilaksanakan, maka dirumuskan hipotesis penelitian dengan rumusan dan simbol sebagai berikut :

Ho = Tidak terdapat pengaruh antara manajemen sumber daya manusia terhadap nilai hasil belajar peserta didik.

$\mathrm{Ha}=$ Terdapat pengaruh antara manajemen sumber daya manusia terhadap nilai hasil belajar peserta didik.

3. Kerangka Pemikiran

Tugas seorang Guru antara lain mencetak peserta didik yang berkualitas dalam bidang iptek dan iptak, untuk mencapai hal tersebut guru sebagai pendidik, berfungsi mengelola, membimbing dan mengarahkan peserta didik agar dapat berprestasi. Berprestasi atau tidaknya peserta didik dipantau dalam aspek kognitif (pengetahuan), afektif (sikap) dan psikomotor (keterampilan).

Untuk mencapai tujuan tersebut, tentu dalam penempatan guru mesti sesuai dengan keilmuan dan pengetahuan yang bersangkutan, dengan kata lain, sesuai dengan jurusan pendidikan guru itu sendiri.

Hal lain yang mesti mendukung di sekolah tersebut yaitu sarana dan prasarana dilingkungan sekolah tersebut mesti mendukung mencetak peserta didik yang berkualitas, karena tanpa sarana dan prasarana yang kurang memadai akan menghambat pencapaian tujuan tersebut.

Di samping lingkungan sekolah, yang mesti terlibat dalam mencapai peserta didik yang berkualitas yaitu keluarga, peran ibu, bapak, kakak dilingkungan keluarga akan berpengaruh pada peserta didik dalam menggapai kualitas dibidang iptek dan iptak.

\section{METODE}

Objek penelitian ini adalah SMPN 11 Kota Tangerang Selatan, dengan subjek yaitu para guru yang bertugas di SMPN 11 Kota Tangerang Selatan. Hal ini dimaksudkan untuk mengetahui pengaruh manajemen sumber daya manusia terhadap nilai hasil belajar peserta didik.

Jenis penelitian yang dilaksanakan yaitu deskriptif asosiatif yang mengungkapkan fakta seberapa erat hubungan dan kontribusi variable manajemen sumber daya manusia $(\mathrm{X})$ sebagai variable bebas dan nilai hasil belajar peserta didik sebagai variable terikat $(\mathrm{Y})$.

Populasi dalam penelitian ini sebanyak 65 guru yang telah memberikan pelajaran pada peserta didik di SMPN 11 Kota Tangerang Selatan.

Tehnik pengambilan sampling digunakan dalam penelitian ini yaitu menggunakan sampling jenuh yakni tehnik penentuan pengambilan sampel semua anggota guru digunakan sebagai sampel.

Metode pengumpulan data yang digunakan untuk penelitian ini yaitu melalui studi pustaka (library research), studi lapangan (field research) dan kuesioner. Untuk mendapatkan data yang relevan, akurat dan reliable dalam penelitian ini menggunakan dua sumber data yaitu data primer dan data sekunder.

\section{HASIL dan PEMBAHASAN}

\section{Karakteristik Responden}

Objek penelitian ini adalah seluruh guru yang bertugas di SMPN 11 Kota Tangerang Selatan, sebanyak 65 responden, dari data tersebut diklasifikasikan sebagai berikut:

a. Responden menurut Jenis Kelamin

\begin{tabular}{|l|c|c|}
\hline \multicolumn{2}{c|}{ Tabel 1. Responden Menurut Jenis Kelamin } \\
\hline \multicolumn{1}{|c|}{ Jenis Kelamin } & Jumlah & Prosentase \\
\hline Pria & 23 & $33,85 \%$ \\
\hline Wanita & 43 & $66,15 \%$ \\
\hline Jumlah & 65 & $100 \%$ \\
\hline \multicolumn{3}{|c|}{ Sumber : Data Primer diolah (2018) } \\
\hline
\end{tabular}

Dari tabel di atas dapat dilihat, responden wanita sebanyak 43 atau $66,15 \%$ dan responden pria sebanyak 25 atau 
$33,85 \%$, hal ini menggambarkan bahwa responden lebih banyak guru wanita dari pada pria.

b. Responden menurut Usia

\begin{tabular}{|c|c|c|}
\hline \multicolumn{3}{|c|}{ Tabel 2. Responden Menurut Usia } \\
\hline Usia (Tahun) & Jumlah & Prosentase \\
\hline $25-30$ & 7 & $10,77 \%$ \\
\hline $30-35$ & 8 & $12,31 \%$ \\
\hline $35-40$ & 4 & $6,15 \%$ \\
\hline $40-45$ & 8 & $12,31 \%$ \\
\hline $45-50$ & 18 & $27,69 \%$ \\
\hline $50+$ & 20 & $30,77 \%$ \\
\hline Total & 65 & $100 \%$ \\
\hline \multicolumn{3}{|c|}{ Sumber : Data Primer diolah (2018) } \\
\hline
\end{tabular}

Dari tabel di atas, diketahui bahwa responden usia 50 tahun ke atas sebanyak 20 responden atau $30,77 \%$, disusul usia 45-50 tahun sebanyak 18 responden atau $27,69 \%$, dan usia 40-45 tahun sebanyak 8 responden atau $12,31 \%$, usia 35-40 tahun sebanyak 8 responden atau $12,31 \%$, serta usia 30-35 tahun sebanyak 8 responden atau $12,31 \%$ dan 25 -30 sebanyak 7 responden atau $10,77 \%$.

c. Responden menurut Pendidikan
Tabel 3. Responden Menurut Pendidikan

\begin{tabular}{|c|c|c|}
\hline Tingkat Pendidikan & Jumlah & Prosentase \\
\hline D3 & 1 & $1,54 \%$ \\
\hline S1 & 52 & $80,00 \%$ \\
\hline S2 & 12 & $18,46 \%$ \\
\hline Total & 65 & $100 \%$ \\
\hline \multicolumn{3}{|c|}{ Sumber : Data Primer diolah (2018) } \\
\hline
\end{tabular}

Bila dilihat dari segi pendidikan Guru pada SMPN 11 Kota Tangerang Selatan ini mayoritas S1 sebanyak 52 orang atau $80 \%$, disusul dengan pendidikan S2 sebanyak 12 orang atau $18,46 \%$, sisanya D3 1 orang atau 1,54\%.

2. Hasil Deskriptif

a. Deskriptif Manajemen Sumber Daya Manusia

\begin{tabular}{|c|c|}
\hline \multicolumn{2}{|c|}{ Tabel 5. Analisa Rentang Skala } \\
\hline Rentang Skala & Keterangan \\
\hline $127-228,6$ & Sangat (Tidak Setuju, Tidak Puas, Tidak baik \\
\hline $228,7-330,3$ & Tidak Setuju, Tidak Puas, Tidak baik \\
\hline $330,4-432$ & Cukup Setuju, Cukup Puas, Cukup Baik \\
\hline $432,1-533,7$ & Setuju, Puas Baik \\
\hline $533,8-635$ & Sangat (Setuju, Puas, Baik) \\
\hline & Sumber : Sugiono (2009) \\
\hline
\end{tabular}

\begin{tabular}{|c|c|c|c|c|c|c|c|c|c|}
\hline \multirow{3}{*}{ No } & \multirow{3}{*}{ Pernyataan } & \multicolumn{5}{|c|}{ Tanggapan } & \multirow{3}{*}{ Total } & \multirow{3}{*}{ Total Skor } & \multirow{3}{*}{$\begin{array}{l}\text { Rata-rata } \\
\text { skor }\end{array}$} \\
\hline & & 5 & 4 & 3 & 2 & \multirow{2}{*}{$\frac{1}{\mathrm{TTS}}$} & & & \\
\hline & & SS & $s$ & KS & TS & & & & \\
\hline 1 & Kemampuan akademik sesuai antara pendidikan dan pekerjaan & 24 & 28 & 11 & 2 & 0 & 65 & 269 & 413,85 \\
\hline 2 & Keahlian dan pekerjaan perlu disesuaikan & 21 & 23 & 16 & 5 & 0 & 65 & 254 & 392,31 \\
\hline 3 & $\begin{array}{l}\text { Pembagian tugas diperlukan antara uraian jabatan dan } \\
\text { pekerjaan }\end{array}$ & 27 & 24 & 8 & 6 & 0 & 65 & 267 & 410,77 \\
\hline 4 & $\begin{array}{l}\text { Pelaksaaan tugas dilaksanakan sepenuh hati dengan resiko } \\
\text { yang akan timbul }\end{array}$ & 21 & 27 & 14 & 3 & 0 & 65 & 261 & 401,54 \\
\hline 5 & $\begin{array}{l}\text { Tugas yang menggunakan teknologi memerlukan keahlian } \\
\text { tersendiri }\end{array}$ & 24 & 24 & 12 & 5 & 0 & 65 & 262 & 403,08 \\
\hline 6 & $\begin{array}{l}\text { Dalam penyelesaian masalah perlu kemampuan yang } \\
\text { disesuaikan keadaan }\end{array}$ & 18 & 30 & 15 & 2 & 0 & 65 & 259 & 398,46 \\
\hline 7 & Keterampilan, pemahaman dan penguasaan materi saya miliki & 24 & 30 & 9 & 2 & 0 & 65 & 271 & 416,92 \\
\hline 8 & Ketelitian dalam menjalankan tugas selalu saya tingkatkan & 24 & 21 & 17 & 3 & 0 & 65 & 261 & 401,54 \\
\hline 9 & $\begin{array}{l}\text { Dalam pengambilan keputusan Kepala Sekolah selalu minta } \\
\text { masukan }\end{array}$ & 25 & 26 & 9 & 5 & 0 & 65 & 266 & 409,23 \\
\hline 10 & $\begin{array}{l}\text { Bekerja innovative dengan gagasan baru dapat meningkatkan } \\
\text { kinerja }\end{array}$ & 22 & 30 & 10 & 3 & 0 & 65 & 266 & 409,23 \\
\hline \multicolumn{2}{|c|}{ Jumlah } & 230 & 263 & 121 & 36 & 0 & 650 & & 4056,92 \\
\hline \multicolumn{2}{|c|}{ Prosentase } & 35,38 & 40,46 & 18,62 & 5,38 & 0,15 & 100 & & \\
\hline \multicolumn{7}{|c|}{ Rata-rata skor } & & & 405,69 \\
\hline & & & & & & & & \multicolumn{2}{|c|}{ Sumber : Data hasil kuesioner (2018) } \\
\hline
\end{tabular}


Hasil rata-rata skor yang diperoleh pada tabel jawaban Manajemen Sumber Daya Manusia di atas sebesar 405,69 dibandingkan dengan tabel rentang skala, masuk dalam interval 330,4 - 432, dengan interprestasi Cukup Baik.

b. Deskriptif nilai hasil belajar peserta didik

Hasil rata-rata skor yang diperoleh pada tabel jawaban nilai hasil belajara peserta didik di atas sebesar $412,46 \mathrm{di}$ bandingkan dengan tabel analisa rentang skala, masuk dalam interval 330,4-432,0 dengan interprestasi cukup baik.

3. Uji Validitas

a. Uji Validitas Variabel Manajemen Sumber Daya Manusia (X)

Setelah dilakukan pengujian dengan menggunakan SPSS 16 maka di dapat hasil sebagai berikut :

Dari tabel di atas, dapat dilihat nilai hasil uji validitas yang kemudian dibandingkan dengan nilai $\mathrm{r}_{\text {tabel }}$ dengan signifikasi 0,05 uji 2 sisi jumlah responden

\begin{tabular}{|c|c|c|c|c|c|c|c|c|c|}
\hline \multirow{3}{*}{ No } & \multirow{3}{*}{ Pernyataan } & \multicolumn{5}{|c|}{ Tanggapan } & \multirow{3}{*}{ Total } & \multirow{3}{*}{ Total Skor } & \multirow{3}{*}{$\begin{array}{l}\text { Rata-rata } \\
\text { skor }\end{array}$} \\
\hline & & 5 & 4 & 3 & 2 & 1 & & & \\
\hline & & SS & $S$ & KS & TS & STS & & & \\
\hline 1 & $\begin{array}{l}\text { Untuk melatih pembiasaan peserta didik di buat latihan sesuai } \\
\text { dengan kompetensinya }\end{array}$ & 23 & 33 & 7 & 2 & 0 & 65 & 272 & 418,46 \\
\hline 2 & $\begin{array}{l}\text { Saya mampu mengerjakan tugas dengan tepat waktu sesuai } \\
\text { Standar Operasi (SOP) }\end{array}$ & 21 & 23 & 17 & 4 & 0 & 65 & 256 & 393,85 \\
\hline 3 & $\begin{array}{l}\text { Bekerjasama antara guru dan orang tua peserta didik selalu } \\
\text { dilaksanakan }\end{array}$ & 29 & 22 & 12 & 2 & 0 & 65 & 273 & 420,00 \\
\hline 4 & $\begin{array}{l}\text { Dengan belajar bersungguh-sungguh nilai akhir peserta didik } \\
\text { akan lebih baik }\end{array}$ & 28 & 28 & 7 & 2 & 0 & 65 & 277 & 426,15 \\
\hline 5 & $\begin{array}{l}\text { Teknologi dan kemahiran menggunakannya dapat mem-bantu } \\
\text { nilai lebih baik }\end{array}$ & 25 & 25 & 10 & 5 & 0 & 65 & 265 & 407,69 \\
\hline 6 & $\begin{array}{l}\text { Peraturan sekolah perlu ditegakan baik kepada guru maupun } \\
\text { peserta didik }\end{array}$ & 21 & 32 & 10 & 2 & 0 & 65 & 267 & 410,77 \\
\hline 7 & $\begin{array}{l}\text { Kenyamanan ruang kelas dapat menambah semangat belajar } \\
\text { peserta didik }\end{array}$ & 24 & 30 & 6 & 5 & 0 & 65 & 268 & 412,31 \\
\hline 8 & $\begin{array}{l}\text { Saya mampu menyelesaikan pekerjaan dengan peralatan kerja } \\
\text { yang sesuai dengan pekerjaanya }\end{array}$ & 23 & 22 & 15 & 5 & 0 & 65 & 258 & 396,92 \\
\hline 9 & Saya selalu mengajak peserta didik berdiskusi berkelompok & 34 & 21 & 7 & 3 & 0 & 65 & 281 & 432,31 \\
\hline 10 & $\begin{array}{l}\text { Saya berusaha menerapkan model pembelajaran yang } \\
\text { menyenangkan bagi peserta didik }\end{array}$ & 22 & 30 & 8 & 5 & 0 & 65 & 264 & 406,15 \\
\hline \multicolumn{2}{|c|}{ Jumlah } & 250 & 266 & 99 & 35 & 0 & 650 & & 4124,62 \\
\hline \multicolumn{2}{|c|}{ Prosentase } & 38,46 & 40,92 & 15,23 & 5,38 & 0,00 & 100,00 & & \\
\hline \multicolumn{9}{|c|}{ Rata-rata skor } & 412,46 \\
\hline & & & & & & & & \multicolumn{2}{|c|}{ Sumber : Data hasil kuesioner (2018) } \\
\hline
\end{tabular}

Tabel 7. Hasil Uji Validitas Variabel X

\begin{tabular}{|c|c|c|c|}
\hline No & Hasil Uji Validitas & $\mathbf{R}_{\text {tabel }}$ & Keterangan \\
\hline 1 & 0.512 & 0,244 & Valid \\
\hline 2 & 0.536 & 0,244 & Valid \\
\hline 3 & 0.548 & 0,244 & Valid \\
\hline 4 & 0.579 & 0,244 & Valid \\
\hline 5 & 0.620 & 0,244 & Valid \\
\hline 6 & 0.585 & 0,244 & Valid \\
\hline 7 & 0.509 & 0,244 & Valid \\
\hline 8 & 0.495 & 0,244 & Valid \\
\hline 9 & 0.593 & 0,244 & Valid \\
\hline 10 & 0.560 & 0,244 & Valid \\
\hline & & Sumber : Hasil Uji validitas data primer dengan SPSS \\
\hline
\end{tabular}

$(\mathrm{n})=65$ dengan $\mathrm{df}=\mathrm{n}-2$, maka di dapat $\mathrm{r}_{\text {tabel }}$ sebesar 0,244 (lihat lampiran tabel r). Secara keseluruhan nilai $r_{\text {hitung }}>r_{\text {tabel' }}$ maka dapat disimpulkan bahwa semua butir instrumen tersebut valid.

b. Uji Validitas Variabel nilai peserta Didik (Y) 


\begin{tabular}{|c|c|c|c|}
\hline \multicolumn{5}{|c|}{ Tabel 8. Hasil Uji Validitas Variabel Y } \\
\hline No & Hasil Uji Validitas & $\mathbf{R}_{\text {tobel }}$ & Keterangan \\
\hline 1 & 0.660 & 0,244 & Valid \\
\hline 2 & 0.665 & 0,244 & Valid \\
\hline 3 & 0.673 & 0,244 & Valid \\
\hline 4 & 0.683 & 0,244 & Valid \\
\hline 5 & 0.702 & 0,244 & Valid \\
\hline 6 & 0.688 & 0,244 & Valid \\
\hline 7 & 0.663 & 0,244 & Valid \\
\hline 8 & 0.653 & 0,244 & Valid \\
\hline 9 & 0.692 & 0,244 & Valid \\
\hline 10 & 0.678 & 0,244 & Valid \\
\hline \multicolumn{4}{|c|}{ Sumber : Hasil Uji validitas data primer dengan SPSS } \\
\hline
\end{tabular}

Dari tabel di atas, dapat dilihat nilai hasil uji validitas yang kemudian dibandingkan dengan nilai $\mathrm{r}_{\text {tabel }}$ dengan signifikasi 0,05 uji 2 sisi jumlah responden $(\mathrm{n})=65$ dengan $\mathrm{df}=\mathrm{n}-2$, maka di dapat $\mathrm{r}_{\text {tabel }}$ sebesar 0,244. Dengan demikian keseluruhan nilai $r_{\text {hitung }}>r_{\text {tabel }}$ maka dapat disimpulkan bahwa semua butir instrumen tersebut valid.

c. Uji Reliabilitas

\begin{tabular}{|c|c|c|c|}
\hline \multicolumn{5}{|c|}{ Tabel 9. Uji Realibilitas } \\
\hline Variabel & Alpha Cronbach's & $\mathbf{r}_{\text {tabel }}(\mathbf{n}=95)$ & Keterangan \\
\hline$X$ & 0.582 & 0,244 & Reliabel \\
\hline$Y$ & 0.694 & 0,244 & Reliabel \\
\hline \multicolumn{4}{|c|}{ Sumber : Hasil Uji realibilitas data primer dengan SPSS } \\
\hline
\end{tabular}

d. Uji Normalitas

\begin{tabular}{|l|l|r|}
\hline \multicolumn{3}{c}{ Tabel 10. Uji Normalitas } \\
\hline \multicolumn{2}{|c|}{ One-Sample Kolmogorov-Smirnov Test } \\
\hline $\mathrm{N}$ & & $\begin{array}{c}\text { Unstandardized } \\
\text { Residual }\end{array}$ \\
\hline \multirow{4}{*}{ Normal Parameters ${ }^{\text {a,b }}$} & Mean & 65 \\
\cline { 2 - 4 } & Std. Deviation & .0000000 \\
\cline { 2 - 4 } & Absolute & 2.66574243 \\
\hline Most Extreme Differences & Positive & .104 \\
\hline & Negative & .069 \\
\hline Kolmogorov-Smirnov Z & & -.104 \\
\hline Asymp. Sig. (2-tailed) & & .836 \\
\hline \multicolumn{2}{|c|}{ Sumber : Hasil uji Normalitas dengan SPSS } \\
\hline
\end{tabular}

Hasil uji Normalitas KolmogorovSmirnov dapat dilihat tabel di atas bahwa nilai signifikasinya $0,486>0,05$ berarti sesuai dengan Kolmogorov-Smirnov de- ngan memakai alpha $5 \%$ nilai signikan > 0,05 , maka data normal.

\section{e. Uji Korelasi Product Moment}

Hasil uji statistik menggunakan SPSS 16 dapat interpretasikan sebagai berikut :

\begin{tabular}{|l|r|r|r|r|}
\hline \multicolumn{6}{c|}{ Tabel 11. Uji Korelasi Product Moment } \\
\hline \multicolumn{7}{|c|}{ Model } & \multicolumn{1}{c|}{ R } & R Square & $\begin{array}{c}\text { Adjusted R } \\
\text { Square }\end{array}$ & $\begin{array}{c}\text { Std. Error of } \\
\text { the Estimate }\end{array}$ \\
\hline 1 & $.723^{\mathrm{a}}$ & .523 & .515 & 3.32705 \\
\hline \multicolumn{6}{|c|}{ Sumber : Hasil uji korelasi dengan SPSS } \\
\hline
\end{tabular}

Berdasarkan output pada tabel di atas, diperoleh nilai koefisien korelasi sebasar 0,723 hal ini menunjukkan antara variable $\mathrm{X}$ dan variable $\mathrm{Y}$ mempunyai hubungan yang kuat.

f. Hasil Uji Koefisien Determinasi

Koefisien determinasi $\left(\mathrm{R}^{2}\right)$ bertujuan untuk mengetahui sebera besar kemampuan variable independen menjelaskan variable dependen, dalam penelitian ini untuk mengetahui sebera besar kontribusi manajemen sumber daya manusia terhadap nilai hasil belajar peserta didik.

\begin{tabular}{|c|c|c|c|c|}
\hline \multicolumn{5}{|c|}{ Tabel 12. Hasil Uji Koefiein Determinasi } \\
\hline \multicolumn{5}{|c|}{ Model Summary ${ }^{b}$} \\
\hline Model & $\mathbf{R}$ & R Square & $\begin{array}{l}\text { Adjusted R } \\
\text { Square }\end{array}$ & $\begin{array}{l}\text { Std. Error of } \\
\text { the Estimate }\end{array}$ \\
\hline 1 & $.723^{\mathrm{a}}$ & .523 & .515 & 3.32705 \\
\hline \multicolumn{5}{|c|}{ Sumber : Hasil uji korelasi dengan SPSS } \\
\hline
\end{tabular}

Hasil uji koefisien determinasi di atas menunjukkan bahwa nilai koefisien determinasi sebesar 52,3\%, hal ini menunjukkan bahwa pengaruh manajemen sumber daya manusia terhadap hasil nilai peserta didik sebesar 52,3\%, sedangkan sisanya dipengaruhi factor lain.

g. Hasil Uji Regresi Linear Sederhana

Tujuan analisis regresi linier sederhana adalah untuk mengukur intensitas hubungan antara dua variable dan membuat prediksi perkiraan nilai X dan Y. 


\begin{tabular}{l|r|r|r|r|r|}
\hline \multicolumn{6}{c|}{ Tabel 13. Hasil Uji Regresi Linear Sederhana } \\
\hline \multirow{3}{*}{ Model } & \multicolumn{1}{|c|}{$\begin{array}{c}\text { Unstandardized } \\
\text { Coefficients }\end{array}$} & \multicolumn{2}{|c|}{ Standardized Coefficients } \\
\cline { 2 - 7 } 1 (Constant) & \multicolumn{1}{c|}{ B } & \multicolumn{1}{c|}{ Std. Error } & \multicolumn{1}{c|}{ Beta } & \multicolumn{1}{c|}{$\mathrm{t}$} & \multicolumn{1}{c|}{ Sig. } \\
\hline VAR00002 & 4.010 & 4.456 & & .900 & .372 \\
\hline
\end{tabular}

Dari hasil output di atas, diketahui nilai konstanta sebesar 4.010 dan nilai koefisien regresi sebesar 0,895 , sehingga persamaan regresi dapat ditulis sebagai berikut : $\mathrm{Y}=4.010+0.895 \mathrm{X}$.

Dari persamaan tersebut dapat diterjemahkan : Konstanta sebesar 4.010 menyatakan bahwa jika tidak ada nilai variable $X$ atau $X=0$, maka nilai $Y$ sebesar 4.010. Koefisien regresi sebesar 0.895 menyatakan bahwa setiap penambahan satu satuan variable $\mathrm{X}$, maka nilai Y bertambah 0,895 .

h. Hasil Uji Parsial (Uji t)

Uji t digunakan untuk mengetahui apakah variabel-variabel independen secara parsial berpengaruh nyata atau tidak terhadap variable dependen. Derajat signikasi yang digunakan 0,05. Apabila nilai signifikan lebih kecil dari derajat kepercayaan, maka hipotesis alternatif diterima, yang menyatakan bahwa suatu variable independen secara parsial mempengaruhi variable dependen. Output hasil uji SPSS 16 sebagai berikut:

\begin{tabular}{|l|r|r|r|r|r|}
\hline \multicolumn{7}{c|}{ Tabel 14. Hasil Uji Parsial (Uji t) $^{\text {Coefficients }}$} \\
\hline \multirow{3}{*}{ Model } & \multicolumn{1}{|c|}{$\begin{array}{l}\text { Unstandardized } \\
\text { Coefficients }\end{array}$} & \multicolumn{2}{|c|}{ Standardized Coefficients } \\
\cline { 2 - 7 } & \multicolumn{1}{c|}{ B } & Std. Error & \multicolumn{1}{c|}{ Beta } & \multicolumn{1}{c|}{$\mathrm{t}$} & \multicolumn{1}{c|}{ Sig. } \\
\hline 1 (Constant) & 4.010 & 4.456 & & .900 & .372 \\
\hline VAR00002 & .895 & .108 & .723 & 8.303 & .000 \\
\hline
\end{tabular}

Dari hasil output nilai $\mathrm{t}$ di atas, dengan melakukan bahan uji hipotesis sebagai berikut :

$\mathrm{Ha}=$ Adanya pengaruh manajemen sumber daya manusia terhadap nilai hasil belajar peserta didik pada SMPN 11 Kota Tangerang
Selatan.

Ho = Tidak adanya pengaruh manajemen sumber daya manusia terhadap nilai hasil belajar peserta didik pada SMPN 11 Kota Tangerang Selatan.

Ketentuan :

$$
\begin{aligned}
& \mathrm{Ha}=\text { diterima jika } \mathrm{t}_{\text {hitung }}>\mathrm{t}_{\text {tabel }} \\
& \mathrm{Ho}=\text { ditolak jika } \mathrm{t}_{\text {hitung }}<\mathrm{t}_{\text {tabel }}
\end{aligned}
$$

Berdasarkan uji $\mathrm{t}$ di atas, ternyata $\mathrm{t}_{\text {hitung }}>\mathrm{t}_{\text {tabel }}$ sebesar $8.303>1.997$, dengan demikian Ha diterima, Ho ditolak. Dengan demikian terdapat pengaruh yang signifikan antara manajemen sumber daya manusia terhadap nilai hasil belajar peserta didik pada SMPN 11 Kota Tangerang Selatan.

\section{SIMPULAN}

Dekripsi jawaban dari pengaruh manajemen sumber daya manusia, mayoritas responden menyatakan bahwa manajemen sumber daya manusia di SMPN 11 Kota Tangerang Selatan dikategorikan Cukup Baik. Hal ini dapat dilihat dari jawaban responden total rata-rata skor sebesar 405,69, termasuk dalam interval dengan interprestasi cukup baik. Hasil deskripsi jawaban dari nilai hasil peserta didik dikategorikan cukup baik. Hal ini dapat dilihat dari jawaban responden total rata-rata skor sebesar 412,46 , termasuk dalam interval dengan interprestasi cukup baik.

Koefisien korelasi antara manajemen sumber daya manusia terhadap nilai hasil peserta didik pada SMPN 11 Kota Tangerang Selatan sebesar 0,723. Hal ini menunjukkan bahwa antara manajemen sumber daya manusia dengan nilai hasil peserta didik di SMPN 11 Kota Tangerang Selatan mempunyai hubungan yang kuat. Berdasarkan hasil perhitungan koefisien diterminasi manajemen sumber daya manusia berpengaruh sebesar 52,3\%. Hipotesis dalam penelitian ini adalah terdapat pengaruh manajemen sumber daya manusia pada nilai hasil peserta didik pada SMPN 11 Kota Tangerang Selatan.

Koefien regresi sebesar 0.895 , menyatakan 
bahwa setiap penambahan satu manajemen sumber daya manusia, maka nilai hasil peserta didik pada SMPN 11 Kota Tangerang Selatan bertambah sebesar 0,895. Manajemen sumber daya manusia dalam hal ini guru memang berpengaruh terhadap nilai hasil belajar peserta didik, namun untuk penentu faktor lain mesti dilakukan penelitian lebih mendalam lagi.

Untuk dapat menentukan berhasil tidaknya seorang guru sebagai pendidik yang melaksanakan tugas fungsinya dalam mengelola, membimbing dan mengarahkan peserta didik yang berkuailitas dalam aspek iptek dan iptak mesti dilakukan penelitian kembali dimasa yang akan datang.

\section{DAFTAR PUSTAKA}

Cahyono, Bambang Tri, (1996). Manajemen Sumber Daya Manusia. Jakarta: Badan Penerbit IPWI.

Cahyono, Bambang Tri, (1996). Manajemen Produksi. Jakarta: Badan Penerbit IPWI.

Dessler, Gary, (1997). Manajemen Sumber Daya Manusia, Jilid 1. Jakarta, PT. Prenhallindo.

Djojonegro, Ing Wardiman, (1997). Lima Puluh Tahun Perkembangan Pendidikan Indonesia. Jakarta: Departemen Pendidikan dan Kebudayaan.

Hasibuan, H. Malayu S.P., (2016). Manajemen Sumber Daya Manusia. Jakarta: PT Bumi Aksara.

Kendall, Kendall, (2007). Analisis dan Perencanaan Sistem. Jakarta, PT. Indeks.

Kotler, Philip, Kevin Lane Keller, (2009). Manajemen Pemasaran Edisi 13, Jilid 1. Jakarta, Penerbit Erlangga.

Kotler, Philip, Swee Hoon Ang, Siew Mang Leong dan Chin Tiang Tan, (1999). Manajemen PemasaranpersepktifAsiaBuku 1. Yogyakarta, PT. Andi.

Laudon, Kenneth C \& Jane P Laudon, (2011). Sistem Informasi Manajemen. Jakarta, Penerbit Salemba Empat.

McLeod, Jr. Raymond dan George P Shell, (2012). Sistem Informasi Manajemen. Jakarta, PT Salemba Empat.

Ndraha Taliziduhu, (1997). Pengantar Teori
Pengembangan Sumber Daya Manusia. Jakarta, Penerbit PT Rineka Cipta.

Panggabean, Mutiara S, (2002). Manajemen Sumber Daya Manusia. Jakarta, Ghalia Indonesia.

Robbins., Stephen P., Mary Coulter, (2007). Manajemen Edisi Kedelapan, Jilid2. Jakarta, PT. Indeks.

Robinson., Pearce, (1997). Manajemen Strategik, Formulasi, Implementasi dan Pengendalian. Jakarta, Bina Aksara.

Robbins, Stephen P, Timothy A Judge, (2015). Perilaku Organisasi. Jakarta, Penerbit Salemba Empat.

Siagian, Sondang P, (2004). Manajemen Sumber Daya Manusia. Jakarta: Penerbit Bumi Aksara.

Sunyoto, Agus, (1999). Manajemen Sumber Daya Manusia. Jakarta: Institut Pengembangan Wiraswasta.

Sugiono, (2009). Metode Penelitian Pendidikan; Pendekatan Kualitatif, Kuantitatif dan R \& D. Bandung: Penerbit CV Alfabeta.

Surachmad, Winarno, (1982). Pengantar Penelitian Ilmiah. Bandung: Penerbit Tasito.

Susanto, Dr Ahmad, MPd, (2013). Teori Belajar dan Pembelajaran di Sekolah Dasar. Jakarta: Penerbit Kencana Prenada.

Thoha, Miftah, (2017). Perilaku Organisasi, Konsep Dasar dan Aplikasinya. Jakarta, Divisi Buku Perguruan Tinggi, PT. Raja Grafindo Persada. 